\title{
Twenty-first-century jeremiad: \\ Contemporary hip-hop and American tradition
}

\section{Paul Williams}

\begin{abstract}
This article explores the work of Immortal Technique and Mr. Lif, two rappers who have used hip-hop to draw attention to the materialism, economic inequality, racism and militarism of twenty-first-century America. Their lyrics are understood here as an evolution of the tradition of the jeremiad, a genre of Puritan sermon given a particularly American intonation in midseventeenth-century New England. This article affirms Bercovitch's (1978) contention that the Puritan jeremiad has had an enduring presence in American culture, although points of distinction between the jeremiad in the seventeenth century and the twenty-first are articulated here. Those differences include the inability to assume a shared listening community and the difficulty of verbally apprehending rampant commercialism when the trails of multinational capitalism run around the globe and through history. This shift in historical context is linked to the elaboration of symbolism used by the hip-hop jeremiahs: figurative language and allusions rapidly accumulate in a frantic attempt to gain critical perspective on an America these rappers believe has erred in its ways - and must expect apocalyptic repercussions as a consequence.
\end{abstract}

\section{Keywords}

jeremiad

Puritan

hip-hop

materialism

Christianity

twenty-first century

The American jeremiad was a ritual designed to join social criticism to spiritual renewal, public to private identity, the shifting "signs of the times" to certain traditional metaphors, themes, and symbols...

Bercovitch 1978: xi

...I dominate guerrilla warfare in the streets

There ain't no way to picture me without a victory speech 
When I reach higher positions

Without the recognition of pissed-on competition

'Cause I conquered their ambitions

In a systematic form like a religious tradition...

Coronel 2001b

Since 2000, a handful of American rappers have consistently and vehemently berated their listeners with their perception of the Bush Administration's corruption, the overlapping of racism and economic exploitation, and dread prophesies about the world's future. The two performers discussed here are Mr. Lif, an African-American Bostonian whose albums include Emergency Rations (2002), I Phantom (2002) and Mo' Mega (2006), and the Peruvian-born Immortal Technique, whose albums Revolutionary Vol. 1 (2001) and Vol. 2 (2003) suggest the flavour of his politics. This century has produced outspoken attacks on contemporary US society from popular rappers, such as Eminem and Kanye West; this article concentrates on relatively peripheral figures in the hip-hop community. Their very marginality is an index of their proximity to an American literary tradition that initially seems, temporally and intellectually, to be some distance from hip-hop in the twenty-first century: the American jeremiad. The tradition of the jeremiad is one of religious and political polemic, and was manifested in oral and print texts in Puritan New England in the second half of the seventeenth century. One of Anglophone North America's first literary genres, it re-accentuated a pre-existing European sermon form with a specifically American voice (Bercovitch 1978: xi). This essay approaches the hiphop song as a text in this tradition, which can be deconstructed using the tools of literary criticism. Scholars cannot re-experience the Puritan sermons of the seventeenth century, although those sermons were sometimes published after their delivery; similarly this study limits itself to the recorded (both on $\mathrm{CD}$ and in reprinted lyrics) forms of hip-hop music. At times this exploration reaches out to extratextual contexts, such as the positioning of songs on albums, but it primarily seeks to understand the formal and rhetorical qualities of these rappers' lyrics as echoes of an extremely longstanding American literary tradition. With reference to John McWhorter's criticisms (2007), the hip-hop scholar Michael Eric Dyson comments that this musical genre is often attacked for being 'thuggish', retarding black social advancement, and abandoning the political (and musical) struggles of the Civil Rights era (2004: xi-xii). Studying their work stylistically and technically reinforces Dyson's observation that hiphop 'is still fundamentally an art form that traffics in hyperbole, parody, kitsch, dramatic license, double entendres, signification, and other literary and artistic conventions to get its points across' (2004: xii). Exploring their proximity to the Puritan jeremiahs, this essay insists upon the artistry of 
these texts, and not measuring their harmful effects on young listeners. This concern with theme and formal delivery does not abandon political concerns, but leads back to such contexts through a heightened appreciation of rhetorical style. Imani Perry raises (without endorsing) the perception that the 'late 1990s witnessed the success of a plethora of MCs with mediocre skills, rhyming primarily about consumerism or murder with mild, watered-down beats and weak production' (2004: 191). The collision of politics and lyrical artistry in the twenty-first-century hip-hop texts under analysis here invites one to revise the judgment that this genre is backsliding in articulacy and political critique.

Locating contemporary hip-hop in relation to the literary tradition of the jeremiad complicates and sidesteps existing debates about the relationship between rappers and public culture in hip-hop studies. Hip-hop has repeatedly been positioned by scholars on the continuum of African-American oral culture, not least in the construction of a dynamic community between performers and listeners. Neal's What the Music Said tracks the evolution of an African-American public sphere through black popular music, concluding with gospel's textures resurfacing in hip-hop music and suggesting that the latter has come to 'embody the communities of resistance and survival that have been historically relevant to black survival' (1999: 172). Toop (1984: 28), Small (1987: 392), Dyson (1993: 16) and Perry (2004: 153) note the affinity between rapping and preaching, although the preachers in mind are members of the black Church, not the Puritans' religious leaders. Mr. Lif's work self-consciously reflects on black oral culture during and since the era of plantation slavery as a resource of collective courage and social memory (Bridgeman and Haynes 2005). However, Puerto Rican Americans have contributed to hip-hop since its modern inception on New York's streets in the 1970s, and have faced considerable challenges to their membership of the hip-hop community (Flores 2004: 72; Shaw 1986: 294). To refer to hip-hop as wholly indebted to black musical traditions seems to risk erasing the Puerto Rican contribution (for example) to the genre. The advantage of aligning certain contemporary hip-hop performers with the jeremiad is that it provides a viable methodology for the speaker-audience relationship without leaning on a model of musical tradition that reduces the genre to the next step in the vernacular cultural production of a specific racial group. ${ }^{1}$ Rose (1994: 85) shows that rap is a collision of cultural, legal and technological musical forces, not a linear extension of African-American oral culture. This essay will show how crucial the memory of enslavement and the ongoing experience of racism are for the hip-hop jeremiahs, ${ }^{2}$ while proposing that additional traditions of public address outside the African-American tradition are being refreshed in their work as part of a re-orientation of

\footnotetext{
${ }^{1}$ Another such model might be Paul Gilroy's notion of the 'politics of transfiguration', a dimension of black vernacular culture which transforms desires and social relations within the racial community, as well as its relation to its erstwhile oppressors', stretching towards new modes of friendship to overcome racial oppression (1996: 37-8).

${ }^{2}$ As indeed they were to an earlier generation of rappers, as Perry discusses in relation to KRS-One (2004: 139-40).
} 
hip-hop culture to the contemporary economic and political moment. This bears out Perry's argument that US hip-hop is a black American musical form with 'multiracial and multicultural origins'. Acknowledging the 'significant contributions of Caribbean, white, and Latino communities and artists' Perry advocates the hybridity of US hip-hop while insisting upon the centrality of African-American musical and oral traditions, the use of African-American Vernacular English, and hip-hop's adopting a 'political location in society distinctly ascribed to black people, music, and cultural forms' (2004: 10). With a slightly different intonation to Perry, it is instructive for hip-hop scholars to think about the genre as a meeting place of traditions in oral culture. I do not argue here that the jeremiad should replace other American traditions as the privileged framework for studying hip-hop.

Discontinuities between the addresses made by the Puritan jeremiahs and their hip-hop successors point to the specificities of the political cultures they speak from. A few notes on the production of the American jeremiad in its classic form will orientate the reader for the following discussion. The settlement of New England during the seventeenth century had never been solely undertaken by the religious communities known as the Puritans, although academic study of the period has understandably been drawn to their dominance, and how the political, intellectual, social and economic environment of Northeast America foreshadowed the growth and culture of the United States of America. The classic jeremiad refers to those sermons delivered by the second generation of New England's religious leaders, particularly from the 1660 s to the $1680 \mathrm{~s},{ }^{3}$ although they endured into the eighteenth century and, for Sacvan Bercovitch (1978), mutated into the rhetoric of Exceptionalism shadowing the course of US history. The jeremiads are closely associated with the sermons given in Boston to coincide with the opening of the annual General Court, a tradition which began in May 1634; from 1667 onwards, these election sermons were usually published. Unsurprisingly for sermons connected intimately to the machinery of civic participation, the jeremiads would 'review...recent afflictions' (Miller 1953: 29) and wrap political instruction within religious guidance, as in Jonathan Mitchell's Nehemiah on the Wall in Troublesom [sic] Times (delivered in 1667). This suggests why, despite the sporadic and sparse translation of Christian 'morality and messages' into hip-hop culture (Perry 2004: 150-2), the jeremiad's trace is present in Mr. Lif and Immortal Technique's lyrics: its blending of religious, civic and political messages permit statements that transmit the universal significance of personal behaviour.

These sermons came to follow a prescribed formula, and were characterized by anger, instruction, and the threat of apocalyptic events in New England's future. The Puritan jeremiahs, such

\footnotetext{
${ }^{3}$ Perry Miller starts the jeremiad in its classic, American phase in 1652, with roots in the late 1640 s, at the moment when vice and corruption became signs of God's wrath for many New England preachers $(1953: 28,30)$.
} 
as Increase Mather, Samuel Hooker, and Cotton Mather, were angry that the growing prosperity of the community seemed to have led to dwindling religiosity in its members, especially the younger generations, whose diminished tenancy with salvation caused their parents' significant consternation and debate (Elliott 1994: 256). ${ }^{4}$ As Samuel Danforth preached in A Brief Recognition of NewEngland's Errand into the Wilderness (delivered in 1670, first published in 1671), the 'solemn and serious' question the General Court must address is 'Whether we have not in a great measure forgotten our Errand into the Wilderness' (1671: 159). Its jeremiahs felt that New Englanders had lapsed into backstabbing, heresy, faithlessness, Sabbath-breaking, litigation, promiscuity, alcoholism, lying, 'swearing and sleeping during sermons', and that perennial fear, 'decay of family discipline' (Miller 1953: 34-6). Commenting on the Pilgrim Fathers' mission of establishing a model Christian community, Perry Miller summarises the position of the second-generation Puritan sermons as follows: 'They say, unanimously, that New England was sent on an errand, and that it has failed' (1956: 2).

As the Puritans scrutinised their internal religious purity, their community faced a stream of external threats. King Philip's War of 1675-76 demonstrated that the relationship between the English settlers and Native America was turning increasingly violent, and the American environment supplied hurricanes, fires, shipwrecks, floods, crop failures, droughts, epidemics and earthquakes (Miller 1956: 6; Elliott 1994: 257; Danforth 1671: 168). All of these events provided the Puritan jeremiahs with evidence that their community was straying from the divine mission the Pilgrim Fathers embarked upon. The jeremiahs' congregations needed the wrath of the clergy to compel them towards greater spirituality and religious observance, and away from the distractions of material wealth: the jeremiad was a vehicle of that anger.

\section{Modern Ills}

For the second- and third-generation Puritan settlers, the consolidation of their community - a dangerous, hard-fought task for their predecessors - was regarded with ambivalence. Their commercial and spatial expansion was a sign of God's blessing, but wealth was perceived to have brought complacency where piety was concerned. For the jeremiahs, this was one reason why God was punishing New England: a lifestyle of sober worship would avert divine wrath (Miller 1953: 52, 329).

\footnotetext{
${ }^{4}$ In 1662, the Boston Synod revised their doctrine, allowing the grandchildren of the Pilgrim Fathers to be baptised even if their parents were unconverted by the Puritans rigorous standards. This decision 'was mockingly labeled [sic] the Half-Way Covenant by its opponents' (Elliott 1994: 256). Edmund S. Morgan (1963) argues this is not evidence of dwindling piety. Rather, the Half-Way Covenant was a commonsensical manoeuvre by New England's religious leaders to keep the younger generation within the orbit of their Church, while signifying public self-declaration of salvation remained necessary to be acknowledged as a full member.
} 
Samuel Danforth praises John the Baptist for practicing an 'austere kind of' worship in the wilderness (1671: 153). Danforth attacked a 'flood' of 'Covetousness [and] Luxury' (1671: 163), equating the accumulation of material comforts to the acquisitiveness prohibited by the Ten Commandments. Sunk in indolence, Danforth saw New Englanders neglecting the strictness of Christian practice which had characterized John the Baptist, Christ's most eminent advance party. The North American wilderness offered the opportunity of pious worship without material distractions. The Puritans were squandering this opportunity, and the jeremiahs generally agreed that disciplinary action could be expected to return God's chosen people to their divine path.

In Mr. Lif's single 'Brothaz' (Haynes and Meline 2006a), one notes similar themes of acquisitiveness and divine retribution:

\author{
Darfur's in a state of emergency \\ It's genocide Code Red Classified \\ If this was Kosovo it'd be over bro \\ But it's brothers so it equals no coverage \\ Mo' sufferage \\ People drawn and quartered \\ Castrated slaughtered \\ Burned disgraced \\ Gang raped displaced \\ While the rest of the world just turns face to chase \\ Some economic goals \\ Balance the lost souls \\ But live it up we 'bout to burn in Hell cause God knows...
}

Hip-hop's jeremiahs add racism to the symptoms of malaise and corruption that the Puritans decried. For Lif, the Western media is uninterested in African atrocities because the victims are non-white. Instead of intervening, 'the rest of the world' chooses to pursue financial gains, turning towards the pursuit of wealth and away from the sight of suffering. These 'economic goals' outweigh the suffering 'lost souls', who possess a lesser exchange value. It is a further indictment of the global capitalist system that the soul can be equated with a financial sum and deemed unprofitable to protect, in direct contradiction to Christ's teachings: 'For what shall it profit a man, if he shall gain the whole world, and lose his own soul? Or what shall a man give in exchange for his soul?' (Mark 8.36-7) Sarcastically, Lif allows listeners the transient pleasure that financial capital provides - because punishment awaits in the 
afterlife. This fits the promise made by the eighteenth-century New England jeremiah Jonathan Edwards in the sermon Sinners in the Hands of an Angry God (1741): the punishment for sinners will be hellfire.

With regard to the pursuit of wealth at the expense of piety and religious practice, the seventeenth-century jeremiahs and Mr. Lif both scorn the illusions of materialism. The rapper Aesop Rock - providing guest vocals on the Lif track 'Take, Hold, Fire' (Haynes, Bavitz and Meline 2006) scorns the listener: 'You bow to a gimmick.' Contemporary United States deifies the latest sales techniques and spiritual malnourishment is the consequence. This scepticism towards capitalist hyperconsumption is partly what Perry identifies as the privileging of authenticity and 'the real' in hiphop culture, which is implicitly political in that calls 'to keep it real' (and not to be seduced by the trappings of commercial success) reveal the illusory satiation that the worlds of labour and consumption provide (2004: 87). Perry notes an alternative current at work in hip-hop: the fetish made of excessive shopping and exhibiting consumer goods. While attempting to read the 'counterhegemonic' force of conspicuous consumption, she acknowledges the difficulties of seeing political and economic critique in 'sartorial stylistic excesses': 'Perhaps the critic should just appreciate the achievements of young black people with global popular culture in their hands and understand that hip hop will never simply embrace one set of progressive politics.' (2004: 196-197) Mr. Lif's position is more strident than Perry's, condemning the fraudulent replacement of meaningful spirituality with meaningless consumption in 'Ultra Mega' (Haynes and Meline 2006b). Referring to clothing and diamond rings, Lif argues that the commodities themselves are of secondary importance, since it is the act of consumption that momentarily quenches perceived lacunae in the self:

Implant impulse

In skulls

Roam the aisles till it feels worthwhile...

Advertising stimulates the belief that the things we buy will fulfil us, and describing this as an 'implant' implies this does not naturally belong in our psyche. 'Implant' invokes an alien probe intruding into our heads, part of Lif's wider symbolic terminology where shopping is an everyday interface with the incomprehensible forces of multinational capitalism - 'Welcome to the realms of the infinite!' - to whose whims the consumer is subject - 'We're a Master Store / But really mainly just Master!' (Haynes and Meline 2006b) The consumer will keep searching the aisles, never finding permanent fulfilment in commodity consumption, as the aimlessness of 'roaming' suggests. 
For hip-hop's jeremiahs, the collusion between racism and multinational capitalism is prominent in the American economy and society. They allege that slavery's injustices remain voluminous in the twenty-first century:

Check to check, constant struggle to make the payments Working your whole life wondering where the day went The subway stays packed like a multicultural slave ship It's rush hour, 2:30 to 8 , non-stoppin'

And people coming home after corporate sharecropping

And fuck flossin', mothers are trying to feed children

But gentrification is kicking them out of their building

A generation of babies born without health care

Families homeless, thrown the fuck off of the welfare...

(Coronel 2003a)

The comparison in 'Harlem Streets' between working for a corporation and sharecropping implies that American workers can merely survive on the money they make. Like sharecroppers, their means of production are owned by someone else profiting from their labour and leaving them the bare minimum to live by and continue working. Immortal Technique formulates a controversial comparison between a subway train full of commuters and a 'multicultural slave ship'. In this simile, the total servitude ('2:30 to 8, non-stoppin') and endless labour ('Working your whole life') that characterised chattel slavery resurfaces as a facet of twenty-first-century capitalism. While this comparison undoubtedly elides the physical torture and enchainment of slaves, the incongruity of the parallel forces listeners to re-evaluate the contemporary sacrificing of life on an existential level, as well as the nature of the subway train and the slave ship as forms of transporting labour. They are markers of the same economic phenomenon at different historical moments. The slave ship stands as an inaugural symbol of global capitalism, with the subway representing a more recent manifestation of the same multinational commodity economy. Impossible to ignore, the slave ship simile organises the semantic force of this section. Technique reminds listeners that contemporary urban life and struggling on low wages is a matter of life and death for some Americans when they cannot afford health insurance premiums.

In his sermon Eye-Salve (published in 1672), Thomas Shepard Jr. warned his congregation not to repeat the sins of the Biblical city of Sodom. Like Immortal Technique in 'Harlem Streets', Shepard censured 'not strengthening the hand of the poor and needy' (257). In a United States that allows this to 
happen, Technique wonders 'if the word of God is lost' (Coronel and Akir 2003). We see in hip-hop's jeremiahs the same 'spiritual pathology' (Buell 1986: 188) diagnosed by the Puritan preachers. Materialism and greed had compromised the religious mission of the colonies, as John Higginson complained: 'it was not for worldly wealth or a better livelihood' that the Puritans colonised New England (1664: 9-10). Increase Mather proclaimed that 'Whereas the first planters...were satisfied with one acre for each person...how have men since coveted after the earth' (1696: 9-10), and measured against the stipulations of the Ten Commandments, covetousness is a major transgression of God's instruction.

Just as the Puritan jeremiahs compressed debates around governance and polity into their sermons, sometimes with a multilayered address to specific figures, the hip-hop jeremiahs speculatively address America's political leaders, whom they blame for contemporary cultural ills. This culpability is projected onto the Bush Administration and the Evangelical Christian rightwing in US politics. Immortal Technique's 'The 4th Branch' provides an elaborate example:

For those who hide behind the false image of the son of man shall stand before God...

The voice of racism preaching the gospel is devilish

A fake church called the prophet Muhammad a terrorist

Forgetting God is not a religion, but a spiritual bond

And Jesus is the most quoted prophet in the Qu'ran

They bombed innocent people, tryin' to murder Saddam

When you gave him those chemical weapons to go to war with Iran...

The Judas I hang with, the guilt of betraying Christ

You murdered and stole his religion, and painted him white

Translated in psychologically tainted philosophy

Conservative political rightwing ideology

Glued together sloppily, the blasphemy of a nation...

(Coronel 2003c)

In contrast to the Puritans, Immortal Technique offers an interpretation of blasphemy as the exploitation of Christianity for political purposes. He accuses the Bush Administration of using the War on Terror as the occasion to go to war for strategic ends against peoples (like America's domestic non-white population) whose lives are devalued because of their skin colour and because they are not Christian. Technique personifies the Christian right in the United States as 'Judas', reversing their claims to speak for God's purposes, asserting they have betrayed Christ's teachings by using Jesus as a 
symbol of white supremacist, rightwing foreign policy; by ignoring how shared belief in God might be a means of uniting people with the language of spirituality; and for deliberately eliding Islam and Christianity's similarities ('Jesus is the most quoted prophet in the Qu'ran') in order to emphasize their differences and particularly the mutually exclusive values of good and evil they represent. ${ }^{5}$ Rhetorically speaking, the deaths of 'innocent people' in the battle against Iraq aligns the US military with King Herod, who, in trying to kill Christ, also slaughtered innocents indiscriminately. Compared to Herod, Judas, the Devil, this 'fake', 'false' Church shames America by espousing the word of Christ blasphemously. The image of Christ that Technique's words conjure is an idol held together as incoherently as their political ideology (which erroneously opposes Christianity and Islam), and dripping in whitewash: America wars in the name of an ersatz Jesus. In the earlier song 'Revolutionary' (2001b) Technique juxtaposes obscenity and religious exhortation, while disavowing any allegations of blasphemy:

My word is through the Father, Holy Spirit and his fucking Son

'Cause when I grab the mic device in front of Christ and start to rip it

I'll make Jesus turn around and say 'Yo Pop this nigga flipped it'

So talk about whatever and be what you wanna be

But don't mistake the way I break the faith for simple blasphemy...

(Coronel 2001b)

Technique rebukes listeners interpreting his casual deployment of references to the Holy Trinity as disrespectful, although it exemplifies the hip-hop trend of using Christ imagery as a form of 'selfaggrandizement' (Perry 2004: 150-1). Technique warns against misreading his position and proclaims his lyrics come to the listener via a Christian idiom. Jesus himself acknowledges that Technique has translated the teachings of Christianity into a twenty-first-century context: in telling the Holy Father that the rapper has 'flipped it' Christ uses a hip-hop phrase to interpret these lyrics as giving a personal

\footnotetext{
${ }^{5}$ Immortal Technique is susceptible himself to recasting history as a Manichean struggle between forces of Good and Evil, but his allegations against the collusion of racism, the War on Terror, the political right and Evangelical Christianity have some weight. The postapocalyptic Left Behind series of novels, written by Tim LaHaye and Jerry Jenkins, follows the seven-year period of Tribulation commencing with God's 'Rapturing up' of the faithful. The Remnant left on Earth still has the opportunity to earn Christian salvation, by fighting against the Antichrist, who will come to power during the Tribulation and create a New World Order. The Antichrist takes the form of the President of Romania, "who uses his promotion to Secretary-General of the UN to create a common European currency and then a Global Community of which he (after his death and resurrection) becomes Potentate with his capital in New Babylon - Baghdad' (Sutherland 2003: 34). LaHaye is the co-founder of the Moral Majority; his wife runs the pressure group Concerned Women for America. LaHaye also founded the Council for National Policy (CNP), an organisation including Congressmen and figureheads from Evangelical Christianity, which aims to bring Church and State closer together. George W. Bush appears to be quietly sympathetic to LaHaye's religious politics - he addressed the CNP in 1999 (Sutherland 2003: 33-5).
} 
gloss to the word of God (the rapper Rhymefest uses the verb 'to flip' in this context; see Lynskey and Simpson 2006). One could interpret Technique's claim to 'make Jesus turn around' as the boast that his rapping re-orientates the teaching of Christ for a contemporary context, and accordingly the next section analyses the hip-hop jeremiahs' attempts to apprehend verbally the networks and power relations of multinational capitalism.

\section{'I am the Lyrical Apocalypse' (Coronel 2001a): The apocalyptic imagination and the paranoid style}

Samuel Danforth wondered whether New England's mid-seventeenth-century problems, especially natural phenomena such as floods, storms and earthquakes, were signs that God was 'making a way for his Wrath' (1671: 168). Apocalyptic warnings were common in the Puritan jeremiad, fitting the jeremiahs' project of urgent instruction to a chosen people at risk of falling from grace. ${ }^{6}$ Cotton Mather proclaimed the imminence of the events in the Book of Revelations, preaching 'there is a REVOLUTION and a REFORMATION at the very Door' (1698: 27). This is the legacy of the European sermons preceding the American jeremiad: named after the Biblical prophet Jeremiah, they warned God's wrath would be visited upon the sins of the addressees. As a narrative of the promised people's decline, the jeremiad was 'a staple of English Reformed Protestantism' (Conforti 2006: 103). However, the possibility of future cataclysm took on a different intonation in New England. The weight of Biblical punishment rested on the Puritans so heavily because, as chosen people, their salvation was more critical for God than the mass of unregenerate Christians. Thus, the jeremiad redirected 'an imperiled people of God toward the fulfillment of their destiny' (Bercovitch 1978: 7-9). The threat of apocalypse was meant to prompt the Puritans back on their course to salvation. Evidently, the more extreme God's prompting, the more important they were in His order of salvation. Hip-hop's jeremiahs, observing history from a twenty-first-century perspective, herald the end of the world in various forms: nuclear war as a product of escalating armaments manufacture, Biblical apocalypse as punishment for human sin, or religious and race wars brought about by the polarisation of humanity during the War on Terror. Using secular and religious imagery, Lif and Technique's doomsdays are directly attributable to the accumulation of immoral actions, and like the Puritan jeremiahs, these apocalypses are not premonitions per se but alarms intended to shock audiences into activity.

Mr. Lif uses apocalyptic imagery in despair at the futurelessness of the United States, hypothesising a nuclear conflict produced by the military-industrial relations thriving in an era of

\footnotetext{
${ }^{6}$ The Puritan jeremiahs' use of apocalyptic imagery was of their era: 'the settlement of New England followed directly upon the revival of interest in the Book of Revelation' (Bercovitch 1978: 69).
} 
multinational capitalism. 'Earthcrusher' speculates that this economic system will lead to nuclear extinction:

...you asked where your tax dollars went to,

So now they have sent you

A demonstration, devastation,

Four billion degrees of presentation,

Courtesy of some major corporations you might have had stock in...

(Haynes and Brockman 2002)

Lif places responsibility for this apocalypse on the shoulders of America's citizens, who paid the taxes that commissioned these weapons, and perhaps bought shares in companies profiting from defence contracts. In this track, there is no flashpoint for nuclear war: the momentum of weapon production and the commercial imperative to justify to stockholders where investment has gone - simply reaches a point where proliferation propels apocalypse.

In 'Point of No Return', Immortal Technique quotes the Bible - 'Wormwood, the Planet X and the Seventh Seal' (Coronel 2003b) - to suggest that the escalating violence around the world will result in divine, apocalyptic intervention. The opening of the sealed book in St. John's prophesy in the Book of Revelation is the first stage leading to Judgement Day, and the opening of the seventh and final seal leads to - amongst other catastrophic and momentous events - a star 'called Wormwood' falling from heaven 'upon the third part of the rivers, and upon the fountains of waters... and the third part of the waters became wormwood; and many men died of the waters, because they were made bitter' (Rev. 8.10-11). Here Technique runs 'Wormwood' and Planet $\mathrm{X}$ together, the latter representing a hypothetical tenth planet in the Earth's solar system, and the lyrical collision of these terms implies their equivalence: a celestial body could fall from the sky as Revelation predicts. Leading up to this Biblical catastrophe is exponentially increasing violence in the form of racial and religious war. The Iraq War is interpreted as the most recent episode on a historical continuum stretching back into prehistory, a brutal Darwinian struggle renewing itself in different epochs:

Concrete jungle, guerrilla war out in the streets

Nat Turner with the sickle, pitchfork and machete

The end of the world, motherfucker you not ready...

The comet that killed the dinosaurs, changing the Earth... 
The evolution of the world, bloody and dramatic

Human beings killing monkeys to conquer the planet

The kingdoms of Africa and Mesopotamia

Machine gunnin' your body with depleted uranium...

(Coronel 2003b)

Technique combines contemporary urban strife with America's history of racial injustice to suggest that an ongoing evolutionary narrative (comet ${ }^{7}$ exterminates dinosaurs, humankind exterminates monkeys) is being played out in the United States and Iraq. In the latter, the depleted uranium bullets used in battle demonstrate that this universal tendency towards extermination is reaching a technical level that could see humankind follow the dinosaurs into extinction. As other species have been erased from the planet, the War on Terror promises to catalyse the end of the world for humanity. According to the Puritan jeremiah Increase Mather, armed conflict was a sign that the Biblical apocalypse was impending: 'dreadful wars...are a sign of Christ's appearing to establish his kingdom on the earth' (1667: 243). On the other hand, human annihilation could be imminent because of a cataclysmic race war that Nat Turner's violent resistance to enslavement foreshadows, or simply ecological catastrophe and increasingly totalitarian forms of social control:

It rains acid, one day the earth will cry from a stone

And you'll be lookin' at the world livin' inside of a dome

Computerized humanity living inside of a clone...

(Coronel 2003b)

Technique exploits the double meanings of the song's title to reverse the apparently resigned, fatalist message that listeners could take away. The 'Point of No Return' means both the dystopian future we inexorably move towards, and the personal 'point of no return' the rapper has reached. Knowing what he now does about past and present American atrocities, he cannot continue in his old life: 'If I turn back now there can never be peace / This is the point from which I will die or succeed... / From now on it can never be the same as before / Cause the place that I'm from doesn't exist anymore...' (Coronel 2003b). These hip-hop jeremiahs do not exploit apocalyptic imagery to consign their audiences to fatalist resignation, but as potential futures that can be averted if their listening communities heed the

\footnotetext{
${ }^{7}$ The comet has important symbolic currency in the Puritans' apocalyptic vocabulary, heralding the end of the world, as well as representing the literal destroyer of the world in the emergent language of Enlightenment scientists and their readers at the end of the seventeenth century (Miller 1956: 229; see also Elliott 1975: 118-9).
} 
threat. The 'end of the world' is a means of urging listeners to embrace political activism in the present to halt disaster in the future: 'I'm sick of feeling impotent, watching the world burn / In the era of apocalypse, waiting my turn' (Coronel 2003a).

While this study connects these apocalyptic warnings to the jeremiad tradition, they also chime with Richard Hofstadter's identification of 'paranoid spokesmen' in his essay 'The Paranoid Style in American Politics' (1964):

The paranoid style [is] a way of seeing the world and of expressing oneself...overheated, oversuspicious, overaggressive, grandiose, and apocalyptic in expression...the spokesman of the paranoid style finds [the hostile and conspiratorial world] directed against a nation, a culture, a way of life whose fate affects not himself alone but millions of others...

(1966: 4)

Apocalyptic sentiments are shared by hip-hop's jeremiahs and Hofstadter's paranoid spokesmen, serving the same function: 'Apocalyptic warnings arouse passion and militancy... they portray that which impends but which may still be avoided' (1966: 30). Especially pertinent in light of 'Point of No Return' is that the paranoid spokesman is 'always manning the barricades of civilisation. He constantly lives at a turning point: it is now or never in organising resistance to conspiracy. Time is forever running out' (1966: 29-30).

Classic conspiracy theory ingredients proliferate in Lif's and Technique's lyrics: Mary Magdalene gave 'birth to children of Jesus' (Coronel 2003a), the US government colludes with the masons to rule the world (Haynes and Brockman 2002), and the Bush Administration engineered the 9/11 terrorist attacks to justify their foreign policy and limit domestic civil liberties, as in Technique's 2004 collaboration with the producer Green Lantern and the rapper Mos Def, 'Bin Laden'. This track features the sample 'Bush knocked down the towers' and Technique rapping that his Administration 'funded Al-Qaeda, and now they blame the Muslim religion / Even though Bin Laden was a CIA tactician / They gave him billions of dollars, and they funded his purpose.' (Coronel and Smith 2004) Referring to the words Novus Ordo Seclorum (Latin for 'New World Order'), which form part of the Great Seal of the United States reproduced on US paper currency, Technique defends his views against the label of paranoia: 'This ain't no alien conspiracy theory, this shit is real / Written on the dollar underneath the Masonic seal' (Coronel and Smith 2004). He protests against being dismissed as a conspiracy theorist by invoking further conspiracies: he alludes to the Illuminati, a society originating in the 1770s (when work started on the Great Seal's design), and links them to the New World Order, a 
shorthand reference in America's survivalist networks to the people planning a dictatorial, one world government in the guise of the United Nations (Hofstadter 1966; Gilroy 2001: 352). For Technique, the ubiquity of the dollar bearing the New World Order's appellation signifies that this threat reaches into the everyday lives of America's citizens.

One can interpret the hip-hop jeremiahs' deployment of conspiracy theories as strategic and figurative. ${ }^{8}$ Noting the attention repeatedly given to multinational capitalism, I understand these references as a way of apprehending this protean economic system. Following Fredric Jameson, the conspiracy theory may be a figuration of the networks of late capitalism stretching across the globe (Jameson 1984). The conspiracy theory finds sense and organisation behind apparently random, unconnected events, such as market crashes and assassinations (Hofstadter 1966). These two examples are not evidence of a deliberate, secret plot, but are manifestations of the mechanisms and reflexes of the global marketplace. Self-identified as representing the working class of America and the Third World, it is unsurprising that hip-hop's jeremiahs find the conspiracy theory useful as a stylistic device. From their assumed position at the margins of economic privilege and political power, conspiracies 'make sense' as an empathetic code about the way the world works. 'Feeling that they have no access to political bargaining or the making of decisions, they find their original conception of the world of power as omnipotent, sinister, and malicious fully confirmed' (Hofstadter 1966: 39). Conspiracy is a rhetorical key, providing a location for these rappers to direct their wrath and suspicion concerning multinational capitalism's uneven distribution of wealth and labour. The example of Novus Ordo Seclorum stands out for pinning the signifier of conspiracy onto the dollar bill. Affecting every aspect of our lives, working invisibly but profoundly, Technique's misreading targets the Illuminati-Masonic plot; nonetheless, Technique's paranoid imagination inspects the dollar bill for conspiracy, a shrewd piece of lyrical dexterity. The dollar is a sign and a vehicle of multinational capitalism's influence, and yet even when held up to the light, this 'conspiracy' goes unseen by the naked eye, visible only in its effects.

Returning Lif and Technique's paranoid style to their participation in a twenty-first-century jeremiad tradition, I contend that their conspiracy theories express suspicion towards overarching systems of economic power and are a figuration of the working class's powerlessness. The relation between the representatives of the poor and exploited speaking back to the forces they perceive as perpetuating injustice is similar to the Puritan jeremiahs' rhetorical adoption of marginality, addressing the larger community from which they feel alienated by the impiety and backsliding of the majority.

\footnotetext{
${ }^{8}$ I would not make this case for all manifestations of the conspiracy theory in hip-hop texts (see Gilroy 2001: 352-3).
} 
Contributing to the explicit critique of multinational capitalism made by the hip-hop jeremiahs are the themes of conspiracy theory and apocalypse, both of which contribute to Technique and Lif's tone of urgency. As with its deployment by the Puritan jeremiahs, apocalypse is not threatened to consign the listening audience to despair: it is a warning that future catastrophe will be the repercussion of present social ills.

\section{The fracturing of symbolic language}

The seventeenth-century jeremiahs used religious language - most importantly, a shared stock of symbolism - to activate the Puritans' sense of themselves as a chosen people. This aspect of the jeremiad is radically sheared off from the rappers discussed here. Two reasons suggest themselves for the fracturing of the Puritan jeremiahs' unitary symbolic language: a history of American atrocity, seen from the perspective of those suffering most from racism and oppression, and the critique of multinational capitalism. Surrounded by this bewildering economic world, Mr. Lif and Immortal Technique escalate their symbolism at a manic pace, in order to make sense of a disorientating global space, to arrest the listener, and to highlight injustice.

Through the rhetoric and force of their argument, and with reference to Biblical texts, the seventeenth-century jeremiahs unified imagery as 'disparate' as food, the refining furnace and birth pains (Bercovitch 1978: 61). The act of deploying such imagery illustrates the tensions of communal address: in theory, such symbolism reminds the listeners that they (in the original performance context, New England's Puritans) are a single, homogeneous unit, whose faithfulness can be counted on to comprehend the references to Judeo-Christian narratives, and to relate that unfolding narrative to their historical position. That the jeremiahs had to knit these images together with such verbal sophistication indicates, rhetorically at least, that communality was willed and invoked, not taken for granted.

The disparate imagery of Lif and Technique abandons the use of symbolism as a unitary, homogenising device, and insists upon the differentiated experience and interpretation of said symbols, which often come from the Judeo-Christian repository: the ship, the flood, and the cleansing fire. Bercovitch refers to Puritan jeremiahs in the 1670 s presenting themselves as holding back the 'floodwaters of apostasy' (1978: 88), a metaphor that assumes physical form in the following lyrics from Mr. Lif. In Increase Mather's jeremiad The Mystery of Israel's Salvation (published in 1667), 'roarings... upon the sea' are interpreted as a sign out of the Book of Chronicles, whereas Lif offers an interpretation of the devastation caused by Hurricane Katrina in 2005 in which racism and poverty are 
axes around which the differential perception of the hurricane and its consequences rotate. Like the seventeenth-century jeremiahs, political leaders are explicitly addressed by Lif:

The Bush Administration's worth nothing

Just fuck 'em! Throw 'em in the barrel, buck 'em!

Oh, you ain't know them flood waters was coming?

You can't smell that African blood running?

Oh, to y'all niggers is worthless or something?

Fuck Clinton too!

You ain't really down because you live uptown, bitch

Rwanda! Check out what we're looking at here across water

In the ghettos, brothers and sisters, it's self slaughter

How could colonized minds lead to such uncivilized times?

(Haynes and Meline 2006a)

The posed responses of individuals and communities to the flood suggests deep divisions in its meanings. ${ }^{9}$ For the Bush Administration, the rising waters that engulfed New Orleans were inconsequential: the human lives threatened were predominantly black and poor, and therefore 'worthless'. Former President Bill Clinton, who stood alongside Bush in appealing for donations to aid the relief effort, sees the floods as a fashionable cause to support as part of the persona he cultivates: a statesman who is 'really down', literate and comfortable with popular African-American culture (see Perry 2004: 120-1). Lif implies that this persona is unsustainable because, by living 'uptown' (which suggests upper-class surroundings), Clinton will never share the conditions of impoverishment that black American culture has often grown out of. Lif simply states 'Rwanda!' The perception that the genocide there in the 1990s was not reacted to quickly enough by the United States demonstrates Clinton's ultimate ignorance of and disregard for black life. For the descendents of slaves ("African blood') threatened by Hurricane Katrina, the flood signifies the neglect of the federal government in failing to repair New Orleans' levees. Knowing 'them flood waters was coming', and that expenditure on flood defence was necessary to prevent New Orleans' submergence, the flood symbolises the negligence of the American state, and justifies anger against it.

\footnotetext{
9 As the title indicates, James Baldwin's book The Fire Next Time (1963) (which referenced the lyrics of an AfricanAmerican spiritual) suggested the waning of the motif of the flood as symbol of God's anger. For Baldwin, far more powerful and appropriate for America's black populace in the early 1960s was the imagery of an apocalyptic conflagration.
} 
Stretching and transforming his symbols, this extract exemplifies the fracturing of symbolic language resulting from these rappers' attempts to twist the jeremiad into a form suitable to apprehend the networks of multinational capitalism. The Bush Administration get sealed in oil barrels, the floods swamping New Orleans become an ocean which slaves were transported across, and their point of origin on the other side of the Atlantic, Africa, becomes a continent where massacres took place in Rwanda which the American President ignored. That genocide is reflected back to the perceived genocide in US urban centres, which in turn becomes a reflection on the 'civilising' of Africans on New World plantations. 2005, the history of the middle passage, the 1990s: Mr. Lif raps across centuries and continents in the space of ten lines and twenty seconds, frantically reaching for images to make the tessellation of racism and capitalism legible in the construction of multinational capitalism, and its enduring, uneven global registers of power. Miller observes in relation to the seventeenthcentury jeremiad that 'art requires conventions which emphasize the relevant aspects of experience' (1953: 31), and the conventions of these rappers, their polyphony of languages and symbols, and slippages across time zones and locations, are the desperate attempt to lend sense to a disorientating twenty-first-century world.

'Point of No Return' makes similar juxtapositions of historical evidence, delivered at speed, minimising any narrative framework that might make the connections between periods explicit:

Life without parole, upstate shackled and trapped

Living in the hole, lookin' at the world through a crack

But fuck that, I'd rather shoot it out and get clapped

I've gone too far, there ain't no coming back for me

Auschwitz gas chamber full of Zyklon-B

Just like the Spanish exterminating Tainos

Raping the black and Indian women, creating Latinos

Motherfuckers made me out of self-righteous hatred

And you got yourself a virus, stuck in the Matrix...

(Coronel 2003b)

Given the time Immortal Technique professes to have spent inside the United States's prison system, it seems fair to see the speaking voice at the start of this extract as a persona of the rapper himself. It may be Technique imagining returning to jail under a life sentence, unable to interact with the wider world, which is only available for observation through a 'crack' in the wall. 'Shackled and trapped', treated 
like a caged animal, this state of perpetual death-in-life is rejected in favour of attacking a racist American state oblivious to the sufferings of the poor. Carrying with him knowledge of social injustice, Technique would rather die striking back at society than living in acquiescence. Perhaps the persona is not rapping about being imprisoned, then, but about living in the United States, regardless of incarceration.

By following his account of literal/existential imprisonment with 'Auschwitz gas chamber full of Zyklon-B', the murderous and immoral actions of the US state are indirectly compared to Nazi Germany, signifier of murderous, dictatorial rule in the twentieth century. Technique implies the American penal system is also organised around the eradication of certain groups considered to be incompatible with the US state. He posits himself as the product of deep historical crimes, and a force of revenge for those crimes. For Technique, the Holocaust in Central Europe has an earlier precedent in the genocide modern European settlers committed in the New World from 1492 onwards. By prefacing his lyrics on the Spanish Conquest with a reference to Auschwitz gas chambers, he frames this historical period as a time of genocide, of 'Spanish exterminating Tainos'. The Taino Indians were the indigenous inhabitants of Hispaniola, the Caribbean island, which Columbus reached on his first voyage in 1492. Within two years of the Spanish arrival, over 50,000 Tainos had died from European diseases. The Native American population of the areas controlled by the Spanish plummeted, largely a result of disease and war. Reading America's Latino population as the resulting racial intermixture of Native Americans, European colonists, and black slaves, a product of the sexual violence committed by Spanish settlers, Technique claims these origins for his own anger. The violence he will use against American society is presented as just repercussion of the circumstances in which the people he claims to represent were introduced to the New World. The Spanish raped their slaves and the indigenous American peoples because 'hatred' meant they saw them as less human. This process of elevating themselves, seeing their actions in accord with God's will, is one reason they could be 'self-righteous' while committing atrocities. The United States of America in the twenty-first century is not a direct successor of the Spanish settlement of the New World, but it is a state founded by European settlers, with a historical disregard for the status of Native Americans, and the exploitation and sexual abuse of transported slaves.

Technique refers to the popular film The Matrix (1999), in which the majority of humans are plugged into a digital simulation of reality which keeps them docile while they are used as human batteries by their robot masters. This popular culture reference is expected to be converted by the listener into a metaphor for the punitive US state that quashes individual freedom, as lambasted at the start of this extract. Technique is the 'virus' corrupting the mainframe of the American society, using 
his music to prevent the populace from being anaesthetised to injustices. The main character in The Matrix is made aware that he is misrecognising the computer simulation as reality, and he joins a guerrilla unit of humans committed to awakening the rest of the populace. Listeners familiar with the film can piece this together with Technique's claims and interpret the allusion as a boast prefiguring his eventual success in mobilising his audience to transform the US state.

From a relatively short extract, this commentary has excavated a litany of historical injustices, allusions, images and rhetorical moves. If the Puritan 'jeremiad is under obligation to look simultaneously backward and forward - back to the purity from which the people have degenerated, ahead to the ultimate vengeance' (Miller 1953: 184), this Peruvian-American in the twenty-first century rejects a narrative of decline for a narrative of ongoing violence and suffering. The past is impure, and future apocalypse may be the logical conclusion of that history of violence, as discussed above. How can the language of religious symbolism be shared when hip-hop's jeremiahs offer a history in which the experience of racism (for example) has fractured the ability to look at the New World without division?

Immortal Technique and Mr. Lif's audiences would not necessarily understand the Puritan jeremiahs' Biblical references or their significance as signifiers on a journey to salvation. When that possibility of salvation is no longer decipherable from a shared symbolic language, the fear of damnation no longer functions as a lever of social manoeuvring. The deployment of symbolism by hiphop's jeremiahs is hectic and heterogeneous, the product of a sense of history and contemporary events in which experience and perspective is differentiated by class and racism. The fractured imagery deployed captures this differentiation, with specific political purposes in mind, memorialising the crimes of the past and addressing the injustices of the present. Given multinational capitalism's perplexing temporal and geographical sprawl, the speed and heterogeneity of imagery used attempts to apprehend its myriad permutations and manifestations. The hip-hop jeremiahs return to their Puritan predecessors' warehouse of symbolism, but combine and reconstitute the elements of language to fit their historical perspective.

\section{Conclusion}

Anger at materialism and spiritual ignorance and an apocalyptic tone are obvious connections between a sermon form given specifically American intonation in the seventeenth century, and certain texts and practitioners active in contemporary American popular culture. Those similarities seemed to be sustained by looking deeper into the aesthetic and structural principles shared by the classic jeremiad 
and twenty-first-century hip-hop culture. The Puritan jeremiahs stressed their disapproving separation from their congregations to reinforce the message that the embryonic community in New England should remember their ancestors' self-conscious rejection of Christendom. The relation of jeremiah to congregation enacted the spatial marginality that the Pilgrim Fathers accepted to offer the world a model of religious worship (Bercovitch 1978: 55). Appropriately, Immortal Technique and Mr. Lif are also on the periphery of the hip-hop music industry, rhetorically converting their relative lack of financial success into an avowal of their anti-commercialism.

Drawing hip-hop's jeremiahs together with the Puritan preachers one final time, for both groups an unshakeable core of values stands amidst their proscriptions. There are fundamental truths in their pronouncements, to be defended and advertised. Thinking about the highly structured nature of the jeremiad (see Elliott 1994) leads us closer to these fundamentals. The New England jeremiahs 'developed, amplified, and standardized a type of sermon for which the rules were as definite as for the ode' (Miller 1953: 29). The tight compositional patterns of the jeremiad can also be applied to those performers discussed here, not in terms of individual songs, but in the structure of Mr Lif and Immortal Technique's key albums, Mo' Mega (2006) and Revolutionary Vol. 2 (2003), respectively. These albums conclude with tracks exhorting unity and the promise that the future will offer peace. In place of consumerism, these tracks celebrate family life, rapping and worship of God. Technique delivers 'One' calmly, rapping 'for my children in the future, waiting to breathe... Believe when I'm gone, and this album's on a library shelf / I'll be one with God and one with you and everything else' (Coronel and Akir 2003). Unlike the violent deaths he prophecies elsewhere, here death returns Technique to a unitary state reconciled to God and the universe. The 'children in the future' are a biological issue which, like the presence of his album, guarantees his longevity. While they are suspended, not yet conceived, describing them as 'waiting to breathe' he imagines them as preformed and ready to be animated with life. Inevitably accepting their existence, the continuity they symbolically provide can be relied upon, and in the future, perhaps unlike Technique's present, they will be able to 'breathe' in an America that no longer stifles individuals (or pollutes the atmosphere). Lif's 'For You' is also addressed to a child who is not conceived, running through potential names before deciding 'I'll leave it up to Mom', imagining the rewards of parenting, and prescribing 'Love' as the 'one thing that may keep you alive in this place'. At odds with contemporary society, 'all that keeps [Lif] going' are his 'Love of flowing [rapping] / Love of family / Plus G.O.D. / All seeing and all knowing' (Haynes 2006). Familial love, God, and the continued presence of hip-hop are the essentials behind the hip-hop jeremiahs' espoused lifestyles. The last verse of 'For You' claims to be written facing the sea in Mexico after 'a long hiatus': only with distance between the speaker and the United States can the 
contemplation of bringing new life into the world be completed: there are 'many other factors that do come into play / And make me hesitate to bring you to this world'. Ultimately, whether the future will be a viable place for children rests upon Christian worship and faith: 'Pray to God and hope for strength to practice healthier ways' (Haynes 2006). ${ }^{10}$

The seventeenth-century debates surrounding the Half-Way Covenant indicate that the Puritans also surveyed the world that their children would live in with trepidation. Coming from regenerate stock, would their descendents be saved in the afterlife like the earlier settlers? Bercovitch suggests the Puritans believed that they would - or at least could. Placing parenthood at the centre of their recipe for a worthy life, accompanied by religious worship, the unity of God's Creation, rapping, and familial bonds, hip-hop's jeremiahs also have an imaginative investment in the next generation. Brought up with 'healthy self-esteem without a selfish dream', the presentation of their innocence illustrates to listeners that human life untainted by aggression or consumer desires is possible.

The jeremiahs of Puritan New England and contemporary American hip-hop rebuke their audiences for their membership of a diseased society. Both read the signs of that pathology in the evidence of racism, stark class division, rampant commercialism and spiritual apathy. The disasters of this present, from war to astral portent, augur an absolute catastrophe to come - although that imagination of apocalypse is rhetorically figured as a potential future, mobilising action and selfreflection in the listening community. Conspiracy theories feature far more prominently in the lyrics of Immortal Technique and Mr Lif than in the sermons of the Puritan jeremiahs, reflecting these rappers' attempts to find the terms necessary to confront the bewildering global network of multinational capitalism. In order to comprehend the diffused history of their economic, social and cultural circumstance the hip-hop jeremiahs deliver a dense concatenation of symbols at breathless speed. The multiple layers of symbolism deployed by Immortal Technique and Mr Lif is very different from the communal meaning that the Puritan jeremiahs could assume they shared with the organic, coherent community their sermons addressed. The rappers often reused the Biblical symbolism of fire and floods, to name just two, but an awareness of oppression and violence running through American history leads Lif and Technique to see the interpretation of their symbols as fractured by race and class divisions. From this perspective, the recent past does not seem like an era of lost piety, reversing the

\footnotetext{
${ }^{10}$ This use of the family as the site of personal and social regeneration is present in other forms of racial nationalism. Gilroy critiques several rappers for reusing this 'trope of race as family' (2004: 91) as a guise under which 'authoritarian pastoral patriarchy' (2004: 89) is resuscitated. Neither Lif nor Technique propose that the family is a unit for reproducing their racial culture, but seeing their children as the standard bearers of their lineage and beliefs strikes one as a patriarchal genealogical claim. One may, like Gilroy, object to the regressive political charge of this trope: it seems to me that to assert the centrality of cultivating one's faith and family in a natural space, using implicitly patriarchal tones, is another reminder of the shadow of the Puritan's culture.
} 
claims of declension made by the seventeenth-century jeremiahs. The last tracks on Mo' Mega and Revolutionary Vol. 2 believe that the next generation might be heir to the simple values the current generation ignores. Whether this is the case is a matter of faith in God.

\section{References}

Baldwin, James (1963), The Fire Next Time, Harmondsworth: Penguin.

Bercovitch, Sacvan (1978), The American Jeremiad, Madison: The University of Wisconsin Press.

Buell, Lawrence (1986), New England Literary Culture: From Revolution Through Renaissance, Cambridge: Cambridge University Press.

Conforti, Joseph A. (2006), Saints and Strangers: New England in British North America, Baltimore: John Hopkins University Press.

Danforth, Samuel (1671), A Brief Recognition of New-England's Errand into the Wilderness, in Michael Warner (ed.), American Sermons: The Pilgrims to Martin Luther King Jr., New York: The Library of America, 1999, pp. 151-171.

Dyson, Michael Eric (1993), Reflecting Black: African-American Cultural Criticism, Minneapolis: University of Minnesota Press.

- (2004), 'Foreword', in Murray Foreman and Mark Anthony Neal (eds.), That's the Joint! The HipHop Studies Reader, New York: Routledge, pp. xi-xiv.

Edwards, Jonathan (1741), 'Sinners in the Hands of an Angry God', in Michael Warner (ed.), American Sermons: The Pilgrims to Martin Luther King Jr., New York: The Library of America, 1999, pp. 347-364.

Elliott, Emory (1975), Power and the Pulpit in Puritan New England, Princeton, NJ: Princeton University Press.

_ (1994), 'New England Puritan Literature', in Sacvan Bercovitch (ed.), The Cambridge History of American Literature, Vol. I, Cambridge: Cambridge University Press, pp. 169-306.

Flores, Juan (2004), 'Puerto Rocks', in Murray Foreman and Mark Anthony Neal (eds.), That's the Joint! The Hip-Hop Studies Reader, New York: Routledge, pp. 69-86.

Gilroy, Paul (1996), The Black Atlantic: Modernity and Double Consciousness, London: Verso.

Originally published in 1993.

- (2001), Against Race: Imagining Political Culture Beyond the Color Line, Cambridge, MA:

Harvard University Press.

— (2004), 'It's a Family Affair', Murray Foreman and Mark Anthony Neal (eds.), That's the Joint! 
The Hip-Hop Studies Reader, New York: Routledge, pp. 87-92. Originally published in Gent

Dent (ed.) (1992), Black Popular Culture, Seattle: Bay Press.

Higginson, John (1664), The Cause of God and His People in New England, Cambridge, MA.

Hofstadter, Richard (1966), 'The Paranoid Style in American Politics', in The Paranoid Style in

American Politics and Other Essays, London: Jonathan Cape, pp. 3-40. Originally published in Harper's Magazine (Nov. 1964).

Jameson, Fredric (1984), 'Postmodernism, or The Cultural Logic of Late Capitalism', New Left Review, 146 (July-Aug.), pp. 53-92.

Lynskey, Dorian, and Simpson, Dave (2006), 'Born Slippy was a greyhound we bet on', Guardian

Unlimited, 24 Feb. http://arts.guardian.co.uk/filmandmusic/story/0,,1716162,00.html. Accessed 16 Jan 2007.

Mather, Cotton (1698), Eleutheria, London.

Mather, Increase (1667), The Mystery of Israel's Salvation, in Alan Heimat and Andrew Delbanco (ed.), The Puritans in America: A Narrative Anthology, Cambridge, MA: Harvard University Press, 1985, pp. 237-246.

-(1696), An Earnest Exhortation, Boston.

McWhorter, John (2007), ‘Acting Up: Going Down', Catalyst, Jan-Feb, pp. 17-19. This article originally appeared in City Journal in 2003.

Miller, Perry (1953), The New England Mind: From Colony to Province, Boston: Beacon Press.

_-(1956), Errand into the Wilderness, Cambridge, MA: The Belknap Press of Harvard University Press.

Mitchell, Jonathan (1667), 'Nehemiah on the Wall in Troublesom [sic] Times', in Michael Warner (ed.), American Sermons: The Pilgrims to Martin Luther King Jr., New York: The Library of America, 1999, pp. 119-150.

Morgan, Edmund S. (1963), 'The Halfway Covenant', in Cushing Strout (ed.), Intellectual History in America: Contemporary Essays on Puritanism, the Enlightenment, and Romanticism, Vol. I, New York: Harper \& Row, 1968, pp. 21-34.

Neal, Mark Anthony (1999), What the Music Said: Black Popular Music and Black Public Culture, New York: Routledge.

Perry, Imani (2004), Prophets of the Hood: Politics and Poetics in Hip Hop, Durham: Duke University Press.

Rose, Tricia (1994), Black Noise: Rap Music and Black Culture in Contemporary America, Hanover: Wesleyan University Press. 
Shaw, Arnold (1986), Black Popular Music in America, New York: Schirmer Books.

Shepard, Jr., Thomas (1672), Eye-Salve, in Alan Heimat and Andrew Delbanco (ed.), The Puritans in America: A Narrative Anthology, Cambridge, MA: Harvard University Press, 1985, pp. 247260.

Small, Christopher (1987), Music of the Common Tongue: Survival and Celebration in Afro-American Music, London: John Calder.

Sutherland, John (2003), 'Be Rapture Ready! The end times are nigh! Rev. of Armageddon: The

Cosmic Battle of the Ages, by Tim LaHaye and Jerry Jenkins', London Review of Books, 25.11 (5 June), pp. 33-35.

Toop, David (1984), The Rap Attack: African Jive to New York Hip Hop, London: Pluto Press.

\section{Discography}

Bridgeman, J. and Haynes, J. (2005), Black Dialogue. In: Black Dialogue. CD. New York: Definitive Jux (DJX103CD). Performed by The Perceptionists.

Coronel, Felipe (2001a), Dominant Species. In: Revolutionary Vol. 1. CD. New York: Viper Records/ Babygrande (BBG-CD-70). Performed by Immortal Technique.

—(2001b), Revolutionary. In: Revolutionary Vol. 1. CD. New York: Viper Records/Babygrande (BBG-CD-70). Performed by Immortal Technique.

(2003a), Harlem Streets. In: Revolutionary Vol. 2. CD. New York: Viper Records/Babygrande (B0009J4090). Performed by Immortal Technique featuring Roc Raida.

— (2003b), Point of No Return. In: Revolutionary Vol. 2. CD. New York: Viper Records/Babygrande (B0009J4O90). Performed by Immortal Technique.

— (2003c), The 4th Branch. In: Revolutionary Vol. 2. CD. New York: Viper Records/Babygrande (B0009J4O90). Performed by Immortal Technique.

Coronel, Felipe, and Akir (2003), One. In: Revolutionary Vol. 2. CD. New York: Viper

Records/Babygrande (B0009J4O90). Performed by Immortal Technique featuring Akir.

Coronel, Felipe, and Smith, Dante Terrell (2004), Bin Laden. In: Green Lantern Instrumentals. Mixtape. No place of publication: Team Invasion (GRNL0007). Performed by Immortal Technique and Mos Def.

Haynes, J. (2002), Home of the Brave. In: Emergency Rations. CD. New York: Definitive Jux (DJX30). Performed by Mr. Lif.

—_(2006), For You. In: Mo’ Mega. CD. New York: Definitive Jux (DJX129CD). Performed by Mr. 
Lif.

Haynes, J., Bavitz, I. and Meline, J. (2006), Take, Hold, Fire! In: Mo’ Mega. CD. New York: Definitive Jux (DJX129CD). Performed by Mr. Lif, Aesop Rock, and El-P.

Haynes, J., and Brockman, Jim (2002), Earthcrusher. In: I Phantom. CD. New York: Definitive Jux (DJX37). Performed by Mr. Lif and Insight.

Haynes, J. and Meline, J. (2006a), Brothaz. In: Mo’ Mega. CD. New York: Definitive Jux (DJX129CD). Performed by Mr. Lif.

(2006b), Ultra Mega. In: Mo’ Mega. CD. New York: Definitive Jux (DJX129CD). Performed by Mr. Lif. 